\title{
DEPTH OF EMBEDMENT OF A SHEET PILE WALL
}

\section{U Jagadeesha}

M.E.,M.I.E.,M.I.S.T.E, Lecturer, Jimma Institute of Technology, Jimma University, Jimma, Ethiopia.

\begin{abstract}
The solution of sheet pile wall problem in geotechnical engineering is almost as old as the sheet pile wall itself. The established method for determining magnitude of embedment depth is well accepted and almost precise. However several approximate methods and charts have been developed over years to simplify the life of practicing engineers in designing sheet pile wall. Those methods use incoherent methods of analysis, complex parameters and graphs difficult for interpolation. Here author has made an attempt to revisit the problem and simplify the determination of embedment depth of sheet pile wall.
\end{abstract}

Keywords: Sheet Pile Wall, Embedment Depth

$* * *$

\section{INTRODUCTION}

The solution of sheet pile wall in geotechnical engineering is as old as the sheet pile wall itself. A fairly accurate, permitted by the nature of problem, solution has been developed long back. It is to be recalled here that it involves some idealizations without which solution becomes complex. Solutions have been developed by idealizing the net horizontal pressures acting on the sheet pile wall and for equilibrium conditions just before failure. Solutions developed are straight forward and analytical. These classical solutions developed have worked well. The structures designed using these methods have performed satisfactorily. Geotechnical engineers have positive concurrence upon these methods of design of sheet pile wall.

However practicing Geotechnical engineers yearn for simple solutions for these problems even though the above mentioned solutions are not cumbersome. Their coveting for such solutions is understandable as they have to solve the same problem several times in a project because of variations of problem parameters. Several attempts have been made in the past to fulfill their desire. They have been briefly discussed below.

\section{PAST STUDIES}

Nataraj and Hoadley (1984) developed a simple procedure for anchored sheet pile wall embedded in sands. They assume same soil parameters for the backfill as well as embedment soil. The method uses a hypothetical constant net pressure distribution above and below the dredge line as shown in Fig. No. 1. $\bar{p}_{\mathrm{a}}$ and $\overline{\mathrm{p}}_{\mathrm{p}}$ are the magnitudes of imaginary constant net pressures above and below the dredge line respectively.

The magnitudes of $\overline{\mathrm{p}}_{\mathrm{a}}$ and $\overline{\mathrm{p}}_{\mathrm{p}}$ are given as $\overline{\mathbf{p}}_{\mathbf{a}}=\mathbf{C k}_{\mathbf{a}} \boldsymbol{\gamma}_{\mathbf{a v}} \mathbf{H}$

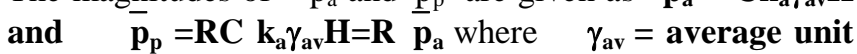
weight of sand $=\left(\gamma \mathbf{h}_{1}+\gamma \cdot \mathbf{h}_{2}\right) /\left(\mathbf{h}_{1}+\mathbf{h}_{2}\right)$

$\mathrm{C}=$ Coefficient $\quad \mathrm{R}=\mathrm{Coefficient}=\mathrm{H}(\mathrm{H}-2 \mathrm{e}) /[\mathrm{D}(2 \mathrm{H}+\mathrm{D}-2 \mathrm{e})]$

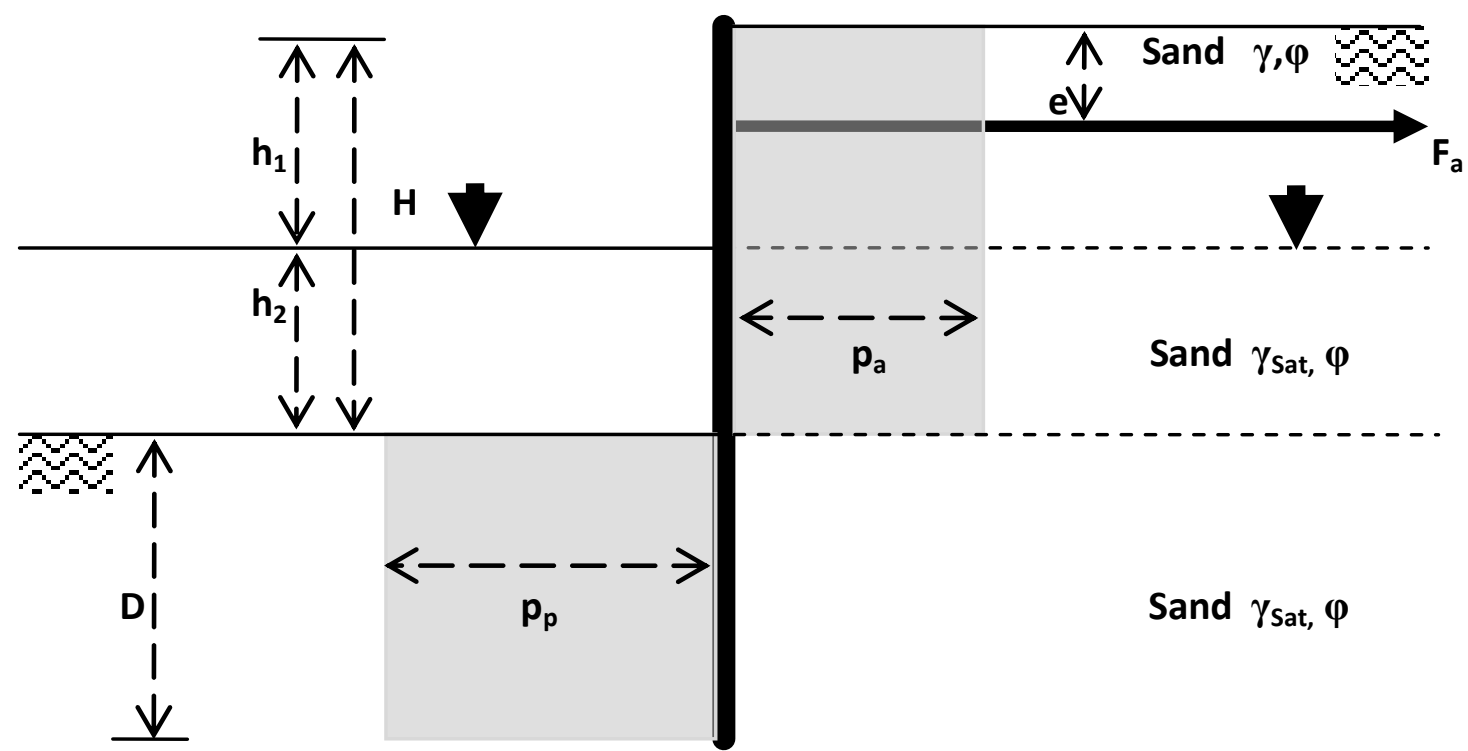

Fig.No.1. Computational pressure diagram method (Nataraj and Hoadley (1984) 
The range of values of $\mathrm{C}$ and $\mathrm{R}$ are given below.

$\begin{array}{lcc}\text { Soil type } & \mathbf{C} & \mathbf{R} \\ \text { Loose sand } & 0.80-0.85 & 0.30-0.50 \\ \text { Medium sand } & 0.70-0.75 & 0.55-0.65 \\ \text { Dense sand } & 0.55-0.65 & 0.60-0.75\end{array}$

The depth of embedment, D is obtained from the following relationship.

$$
D^{2}+2 D H[1-(e / H)]-H^{2} / R[1-2(e / H)]=0
$$

The above equation gives $\mathrm{D}$ about 1.25 to 1.5 times that given by free earth support method. As such factor of safety may not be applied for $D$.

Design charts are developed as an expedient tool for analysis of sheet pile walls embedded both in granular and cohesive soils and for cantilever sheet pile wall and anchored sheet pile wall (free earth support method).In all cases backfill is taken to be granular soil.

For sheet pile walls embedded in granular soil one has to approach the charts with the values of $\gamma^{\prime} / \gamma, \mathrm{k}_{\mathrm{p}} / \mathrm{k}_{\mathrm{a}}$ and ' $\alpha$ '. $\gamma^{\prime}$ is the submerged unit weight of backfill,$\gamma$ is the bulk unit weight of backfill, $\mathrm{k}_{\mathrm{p}}$ is the passive pressure co efficient for embedment soil, $\mathrm{k}_{\mathrm{a}}$ is the active pressure co efficient for backfill soil and ' $\alpha$ ' is the ratio of depth of water table $\left(\mathrm{h}_{1}\right)$ to height of back fill(H).

For sheet pile walls embedded in cohesive soil one has to approach the charts with the values of $\gamma^{\prime} / \gamma$, cohesion ratio [(4c-q)/ $\gamma$ ' $\left.\mathrm{k}_{\mathrm{a}} \mathrm{H}\right]$ and ' $\alpha$ '. $\gamma$ ' is the submerged unit weight of backfill, $\gamma$ is the bulk unit weight of backfill, $\mathrm{c}$ is the cohesion of the embedment soil, $\mathrm{q}$ is the over burden pressure due to backfill at the level of dredge line, $\mathrm{k}_{\mathrm{a}}$ is the active pressure co efficient for backfill soil and ' $\alpha$ ' is the ratio of depth of water table $\left(h_{1}\right)$ to height of back fill $(H)$.

The charts gives the values of $\mathrm{D} / \mathrm{H}$ ratio, $\mathrm{M}_{\max } / \gamma^{\prime} \mathrm{k}_{\mathrm{a}} \mathrm{H}^{3}$ and $\mathrm{F}_{\mathrm{a}} / \gamma^{\prime} \mathrm{k}_{\mathrm{a}} \mathrm{H}^{2}$ knowing whose values $\mathrm{D}, \mathrm{M}_{\max }$ and $\mathrm{F}_{\mathrm{a}}$ can be computed.

Sample charts for this method for cantilever sheet pile wall embedded in sand for $\gamma^{\prime} / \gamma=0.4$ and cantilever sheet pile wall embedded in cohesive soil for $\gamma^{\prime} / \gamma=0.6$ is given below in Fig. No. 2. and Fig. No. 3. respectively.

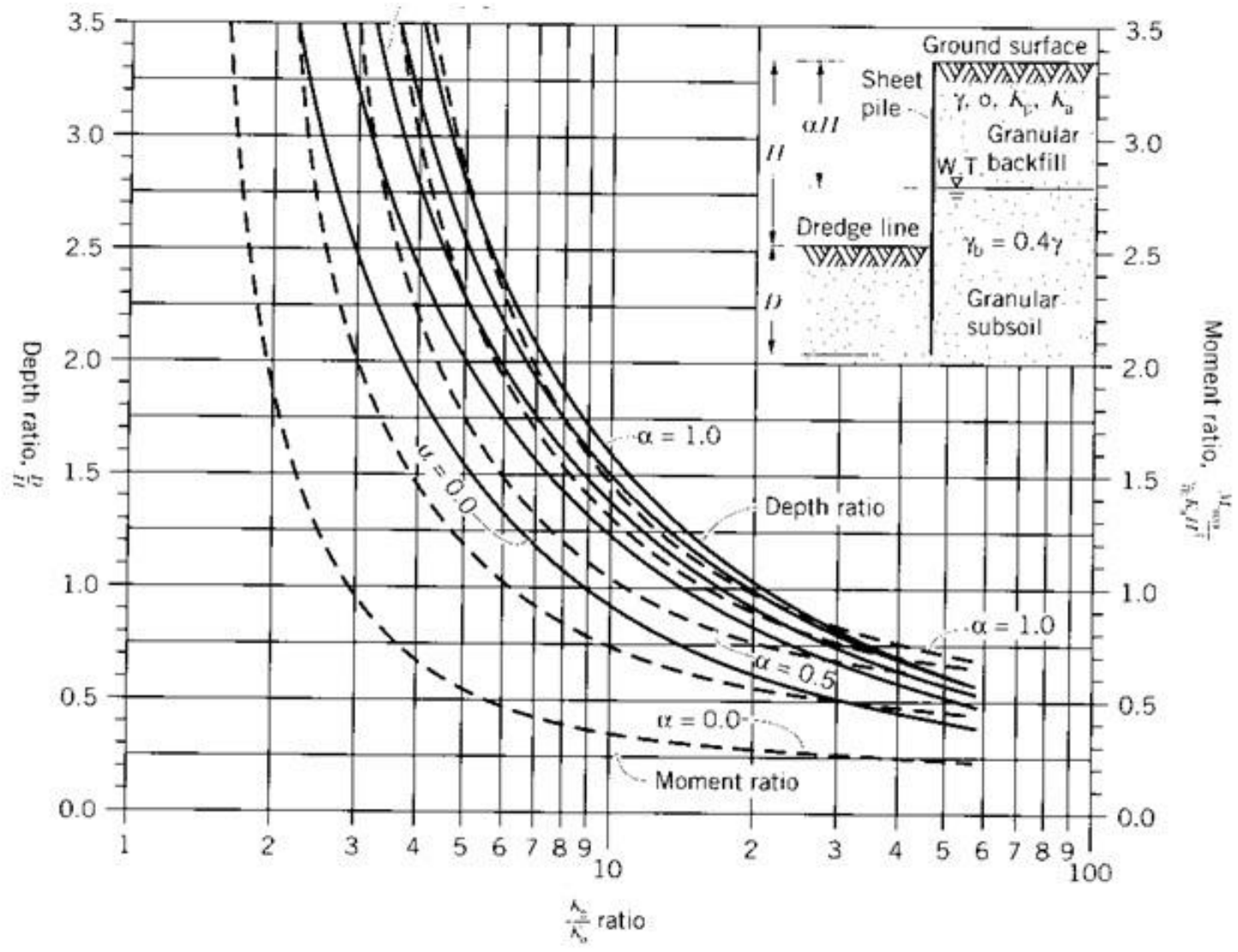

Fig.No.2. Chart to determine $\mathrm{D}$ and $\mathrm{M}_{\mathrm{Max}}$ for a cantilever sheet pile wall embedded in sands 


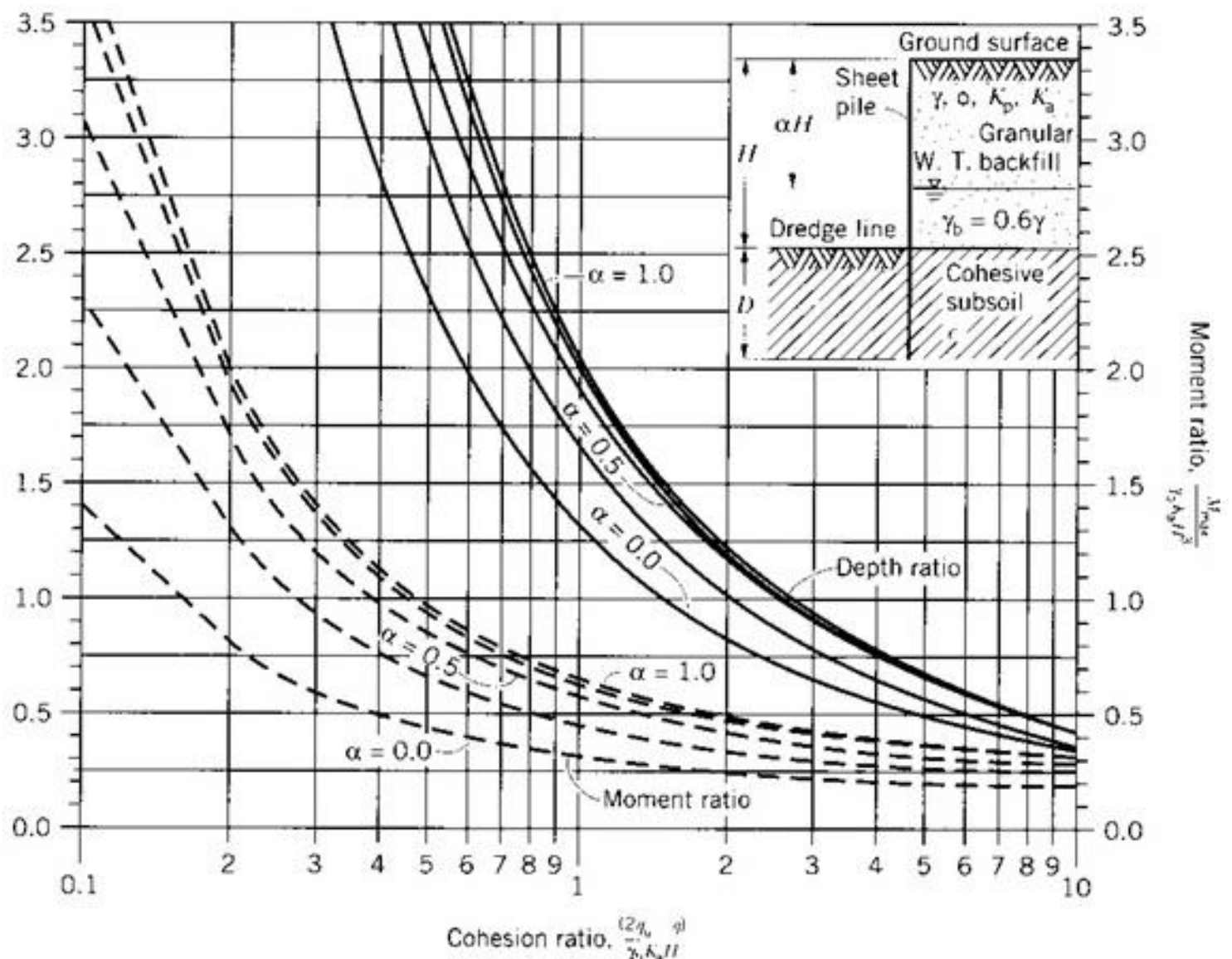

Fig.No.3. Chart to determine $\mathrm{D}$ and $\mathrm{M}_{\mathrm{Max}}$ for a cantilever sheet pile wall embedded in clays.

Hagerty and Nofal (1992) provided design charts for quick estimation of $\mathrm{D}$ for anchored sheet pile penetrating in to sandy soils, as shown in Fig.No.4. They made following assumptions in their analysis.

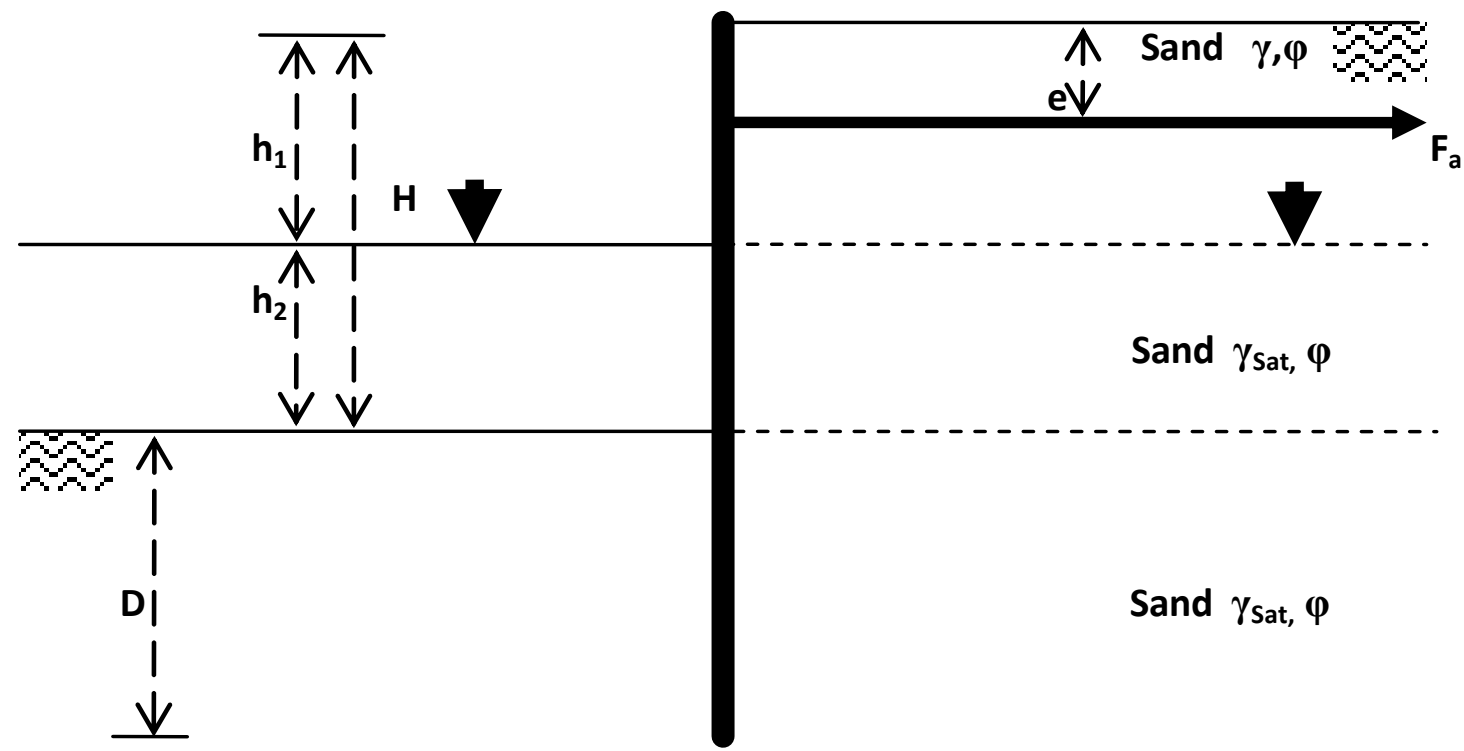

Fig. No. 4. Nomenclature associated with Hagerty and Nofal analysis.

(a)The soil friction angle, $\phi$, above and below the dredge line is the same.

(b)The angle of friction between the wall and the soil is $\phi / 2$.

(c)The passive earth pressure below the dredge line has a logarithmic spiral failure surface.
(d)For active earth pressure calculation, Coulomb's theory is valid.

The magnitude of $\mathrm{D}$ is obtained from the following relationship. 


\section{$\left.\mathrm{D} /\left(\mathrm{h}_{1}+\mathbf{h}_{2}\right)\right]=(\mathrm{GD})\left(\mathrm{CDh}_{1}\right)$}

Where $\gamma_{\mathrm{a}}=$ average unit weight of soil

$=\left[\gamma_{\mathrm{a}} \mathbf{h}_{1}{ }^{2}+\left(\gamma_{\mathrm{sat}}-\gamma_{\mathrm{w}}\right) \mathbf{h}_{2}{ }^{2}+2 \gamma \mathbf{h}_{1} \mathbf{h}_{2}\right] /\left(\mathbf{h}_{1}+\mathbf{h}_{2}\right)$

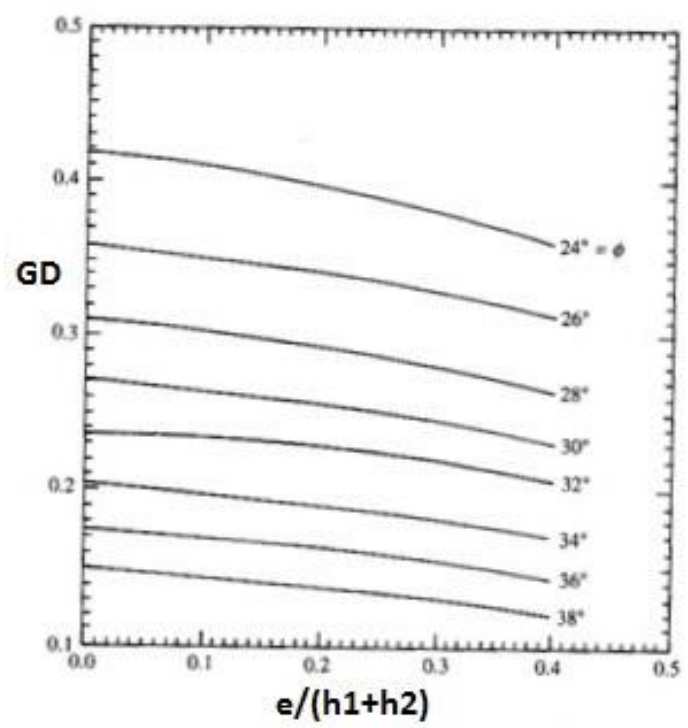

Where GD is generalized non dimensional embedment depth of wall and $\mathrm{CDh}_{1}$ is correction factor for $\mathrm{h}_{1} \neq 0$.

With the values of $\phi,\left[\mathrm{e} /\left(\mathrm{h}_{1}+\mathrm{h}_{2}\right)\right]$ and $\left[\mathrm{h}_{1} /\left(\mathrm{h}_{1}+\mathrm{h}_{2}\right)\right]$ charts (Fig. No. 5) should be approached and the values of GD and $\mathrm{CDh}_{1}$ can be obtained, using which $\mathrm{D}$ can be determined.

Fig. No. 5. Generalised depth and correction factor ( Hagerty and Nofal (1992)).

\section{NEW APPROACH}

The above methods discussed give the values of embedment depth to reliable accuracy. However the author feels they have limitations. The method suggested by Nataraj and Headley (1984) is limited to sandy soils and involves misleading imaginary net pressure distributions. The second method involves interpolation between charts; however it is exhaustive and accurate. It also involves very complex parameter in the form of cohesion ratio, for sheet pile walls embedded in cohesive soils. The third method is limited to anchored sheet pile walls and those embedded in sands. This thinking of the author compels him to search for direct realistic parameters affecting the embedment depth of sheet pile wall and develop correlation between those parameters and embedment depth D. However this study is limited to the search of the correlation mentioned above in case of sheet pile walls embedded in cohesive soils.

\section{CANTILEVER SHEET PILE WALL}

Fig. No. 6. Shows a cantilever sheet pile wall embedded in clay along with heights and relevant soil properties. The equation for embedment depth for equilibrium for a cantilever sheet pile wall embedded in clay is

$D^{2}(4 c-q)-D\left(2 R_{a}\right)-R_{a}\left(12 c y+R_{a}\right) /(2 c+q)=0$

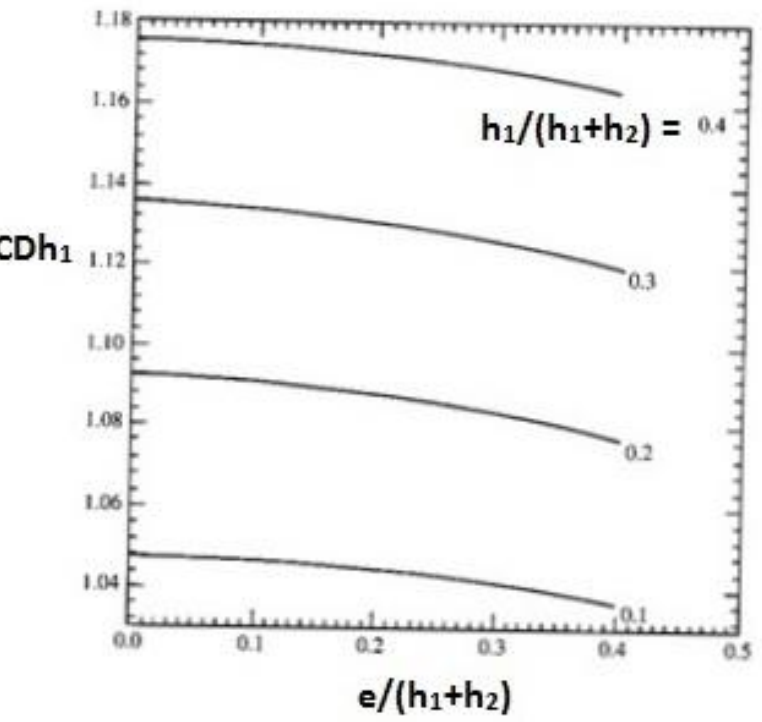

From the equation it is evident that embedment depth $\mathrm{D}$ is dependent on $\mathrm{R}_{\mathrm{a}}, \mathrm{y}, \mathrm{q}$ and $\mathrm{c}$. From the equation and the diagram showing the net pressure distribution against the sheet pile wall (Fig. No. 7.), one can easily recognize that D is directly proportional to $\mathrm{R}_{\mathrm{a}}, \mathrm{y}$ and $\mathrm{q}$ while it is inversely proportional to $\mathrm{c}$. So author has tried to investigate the relationship between these parameters and the positive or practically acceptable root (embedment depth for sheet pile wall) of the above equation.

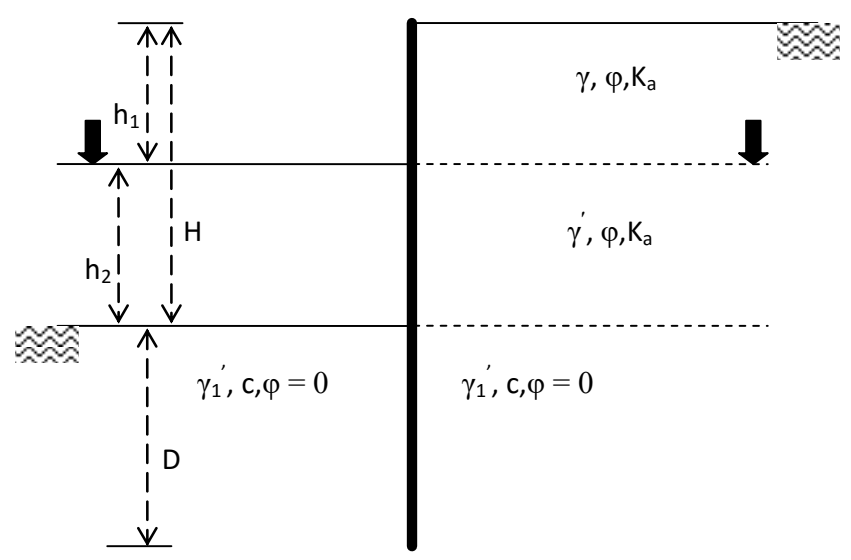

Fig. No. 6. Cantilever sheet pile wall embedded in cohesive soil 

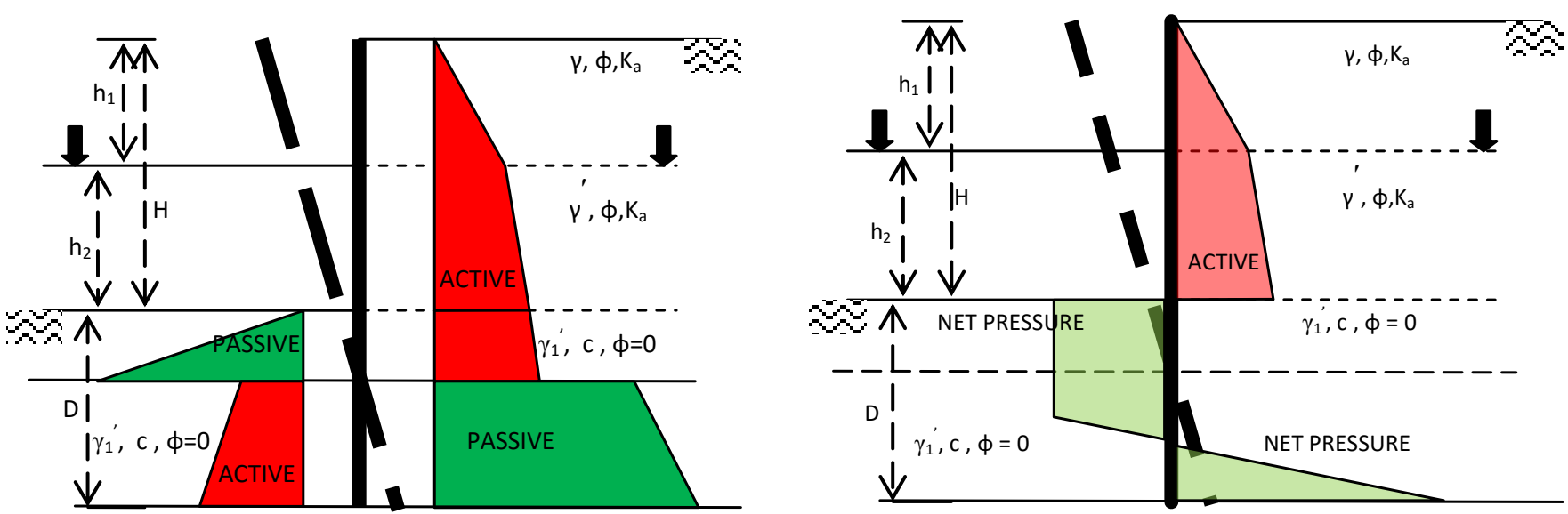

Fig. No. 7. Active and Passive and net pressure distribution against cantilever sheet pile wall embedded in cohesive soil.

Fig. No. 8. gives the variation of $\mathrm{D}$ with $\mathrm{q}$ keeping all other parameters namely $\mathrm{R}_{\mathrm{a}}$, $\mathrm{y}$ and $\mathrm{c}$ constant. From the graph we can see $\mathrm{q}$ influences the embedment depth very marginally for lower heights of retained soil. However for higher heights of soil retained the influence of $\mathrm{q}$ on embedment depth cannot be ignored or we cannot take $\mathrm{D}$ is independent of $\mathrm{q}$. There is a direct linear relationship between $\mathrm{q}$ and $\mathrm{D}$.

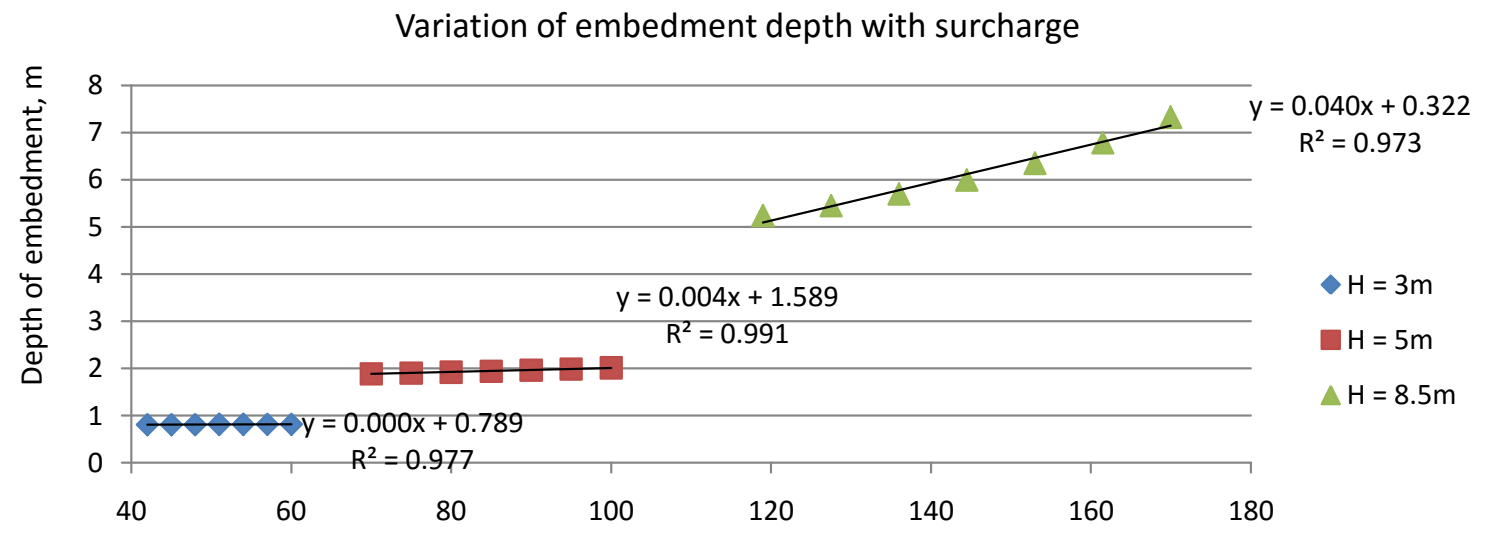

Surcharge at the level of dredge line $\mathrm{q}, \mathrm{kPa}$

Fig. No. 8. Variation of embedment depth with surcharge

Similarly keeping $\mathrm{R}_{\mathrm{a}}$, $\mathrm{q}$ and c constant we can calculate $\mathrm{D}$ for different values of y. Fig. No. 9. is the relationship between $\mathrm{D}$ and $\mathrm{y}$ while other influencing parameters are kept constant. We can see a direct linear relationship between $\mathrm{y}$ and $\mathrm{D}$.

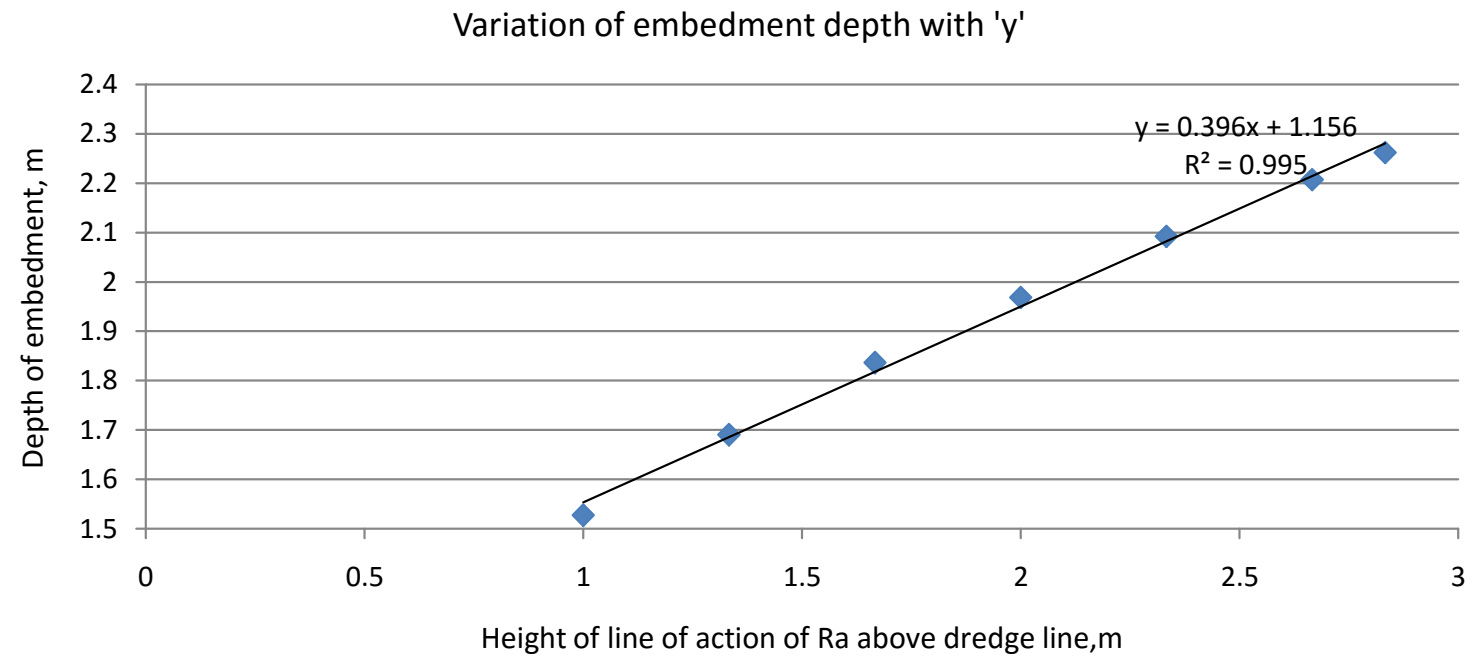

Fig. No. 9. Variation of embedment depth with ' $y$ ' 
Similarly keeping $\mathrm{R}_{\mathrm{a}}$, $\mathrm{q}$ and y constant we can calculate $\mathrm{D}$ for different values of c. Fig. No. 10. is the relationship between $\mathrm{D}$ and $\mathrm{c}$ while other influencing parameters are kept constant. We can see an inverse power relationship between $\mathrm{y}$ and D, off course with little deviations which can be ignored.

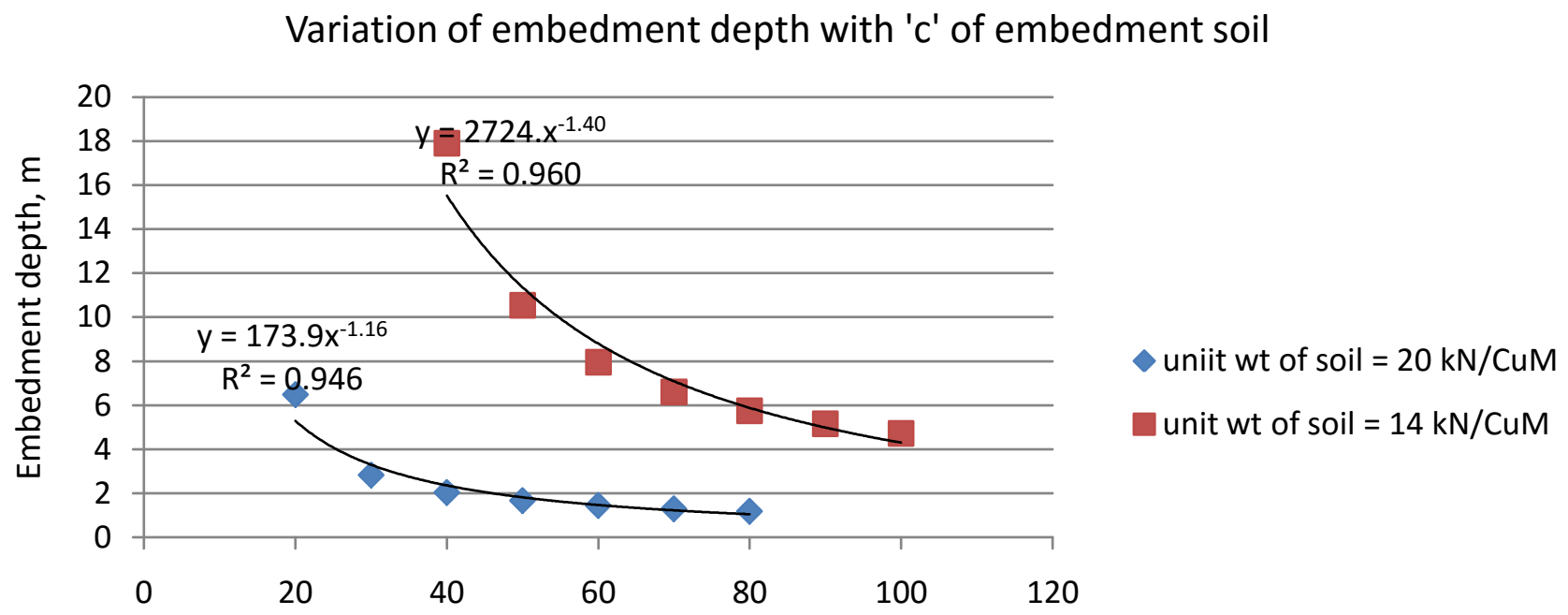

Cohesion of embedment soil, $\mathrm{kPa}$

Fig. No. 10. Variation of embedment depth with cohesion of embedment soil

Likewise keeping c, $\mathrm{q}$ and y constant we can calculate D for different values of $R_{a}$. Fig. no. 11 . is the relationship between $D$ and $R_{a}$ while other influencing parameters are kept constant. We can see a direct linear relationship between $\mathrm{R}_{\mathrm{a}}$ and $\mathrm{D}$, off course with little deviations which can be ignored.

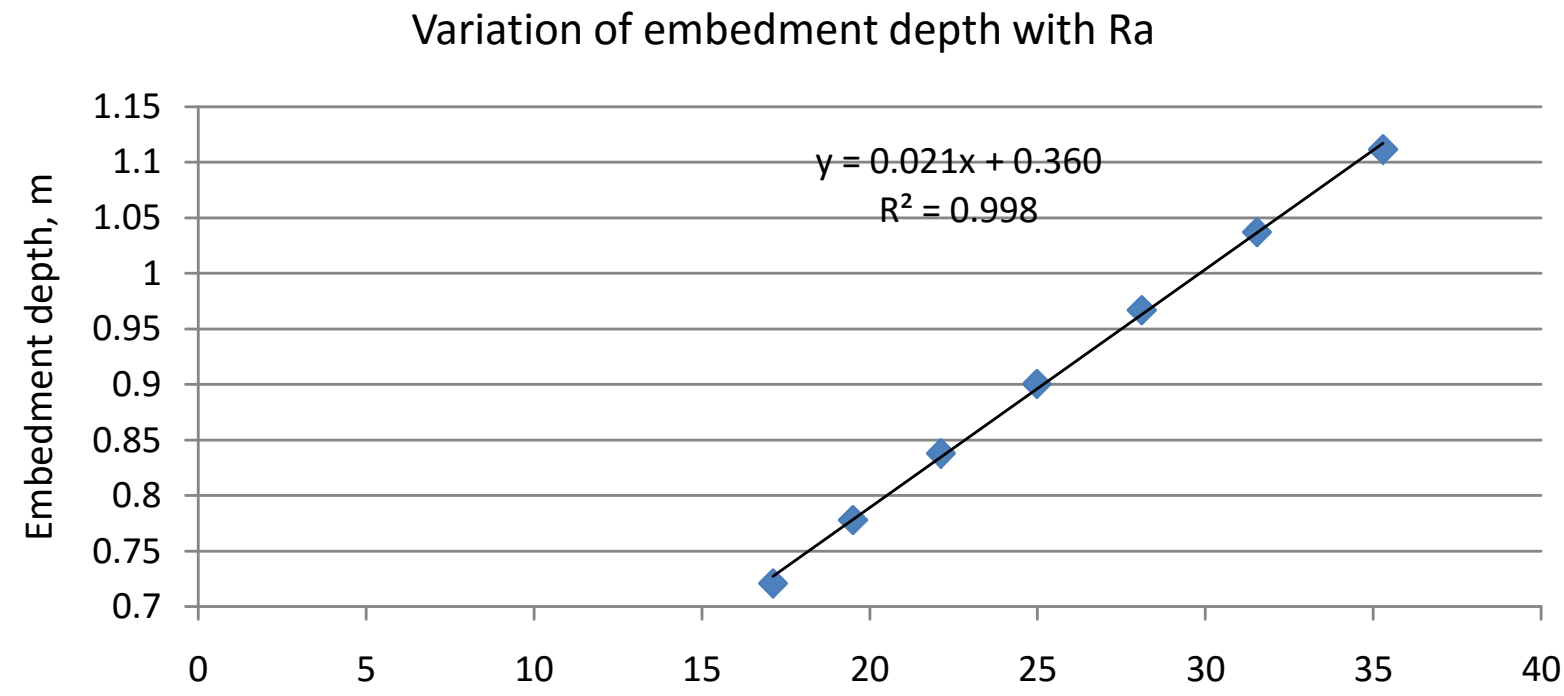

Resultant active force above dredge line, $\mathrm{kN}$

Fig. No. 11. Variation of embedment depth with Resultant active force above dredge line

Combining all these dependencies of $\mathrm{D}$ with $\mathrm{R}_{\mathrm{a}}, \mathrm{y}, \mathrm{q}$ and $\mathrm{c}$ will not be easier. One should note that $\mathrm{D}$ is a function of four variables and working out dependency of D separately with each variable does not ease our burden of working out how D varies with combined effect of those variables. However it gives us an idea about dependency of D with combined effect of these variables.

Let us see the interdependency of these four variables among themselves or as influencing the embedment depth
D. Here $\mathrm{R}_{\mathrm{a}}=0.5 \mathrm{k}_{\mathrm{a}} \gamma \mathrm{H}^{2}, \mathrm{q}=\gamma \mathrm{H}$ and $\mathrm{y}=\mathrm{H} / 3$ are dependent on $\gamma$ and $\mathrm{H}$. all these parameters influence the values of $\mathrm{D}$ directly. The cohesion of embedment soil influences the embedment depth inversely and seems does not have a linear relationship. As such author has tried finding relationship of several combined parameters $\gamma \mathrm{H} / \mathrm{c}^{1.3}, \gamma \mathrm{H} / \mathrm{c}^{1.2}$, $\gamma \mathrm{H} / \mathrm{c}^{1.1} \gamma \mathrm{H} / \mathrm{c}$ and $\gamma \mathrm{H} / \mathrm{c}^{0.9}$ with $\mathrm{D} / \mathrm{H}$. The result of the effort is shown below in Fig. No. 12. 


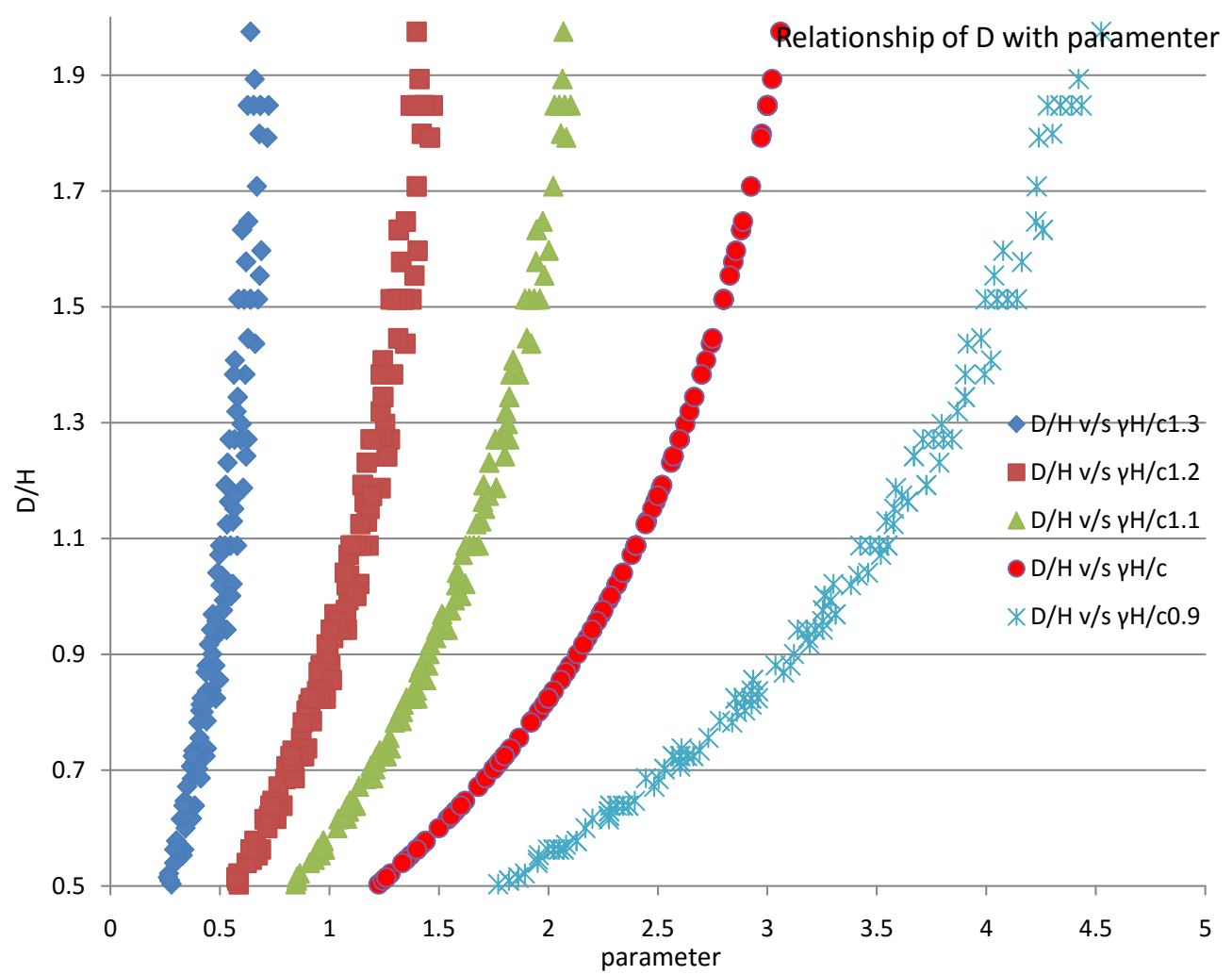

Fig. No. 12. Variation of $\mathrm{D} / \mathrm{H}$ with $\gamma \mathrm{H} / \mathrm{c}^{1.3}, \gamma \mathrm{H} / \mathrm{c}^{1.2}, \gamma \mathrm{H} / \mathrm{c}^{1.1} \gamma \mathrm{H} / \mathrm{c}$ and $\gamma \mathrm{H} / \mathrm{c}^{0.9}$

From Fig. No. 12. we can notice that $\mathrm{D}$ is having a unique relationship with $\gamma \mathrm{H} / \mathrm{c}$ and not with $\gamma \mathrm{H} / \mathrm{c}^{\mathrm{n}}$. Hence the author chooses $\gamma \mathrm{H} / \mathrm{c}$ as the input parameter and tries to establish its relationship with embedment depth of a cantilever sheet pile wall and an anchored sheet pile wall embedded in cohesive soil.

The following Fig. No. 13. depict the relationship between non dimensional parameters $\gamma \mathrm{H} / \mathrm{c}$ and $\mathrm{D} / \mathrm{H}$ for a cantilever sheet pile wall retaining sand and embedded in clay. We should notice that the author deliberately left out $\mathrm{k}_{\mathrm{a}}$ or in turn $\varphi$ in the non dimensional parameter even though it influences the magnitude of $\mathrm{R}_{\mathrm{a}}$ and in turn the magnitude of D. As such we get different relationships for different values of angle of internal friction of retained soil.

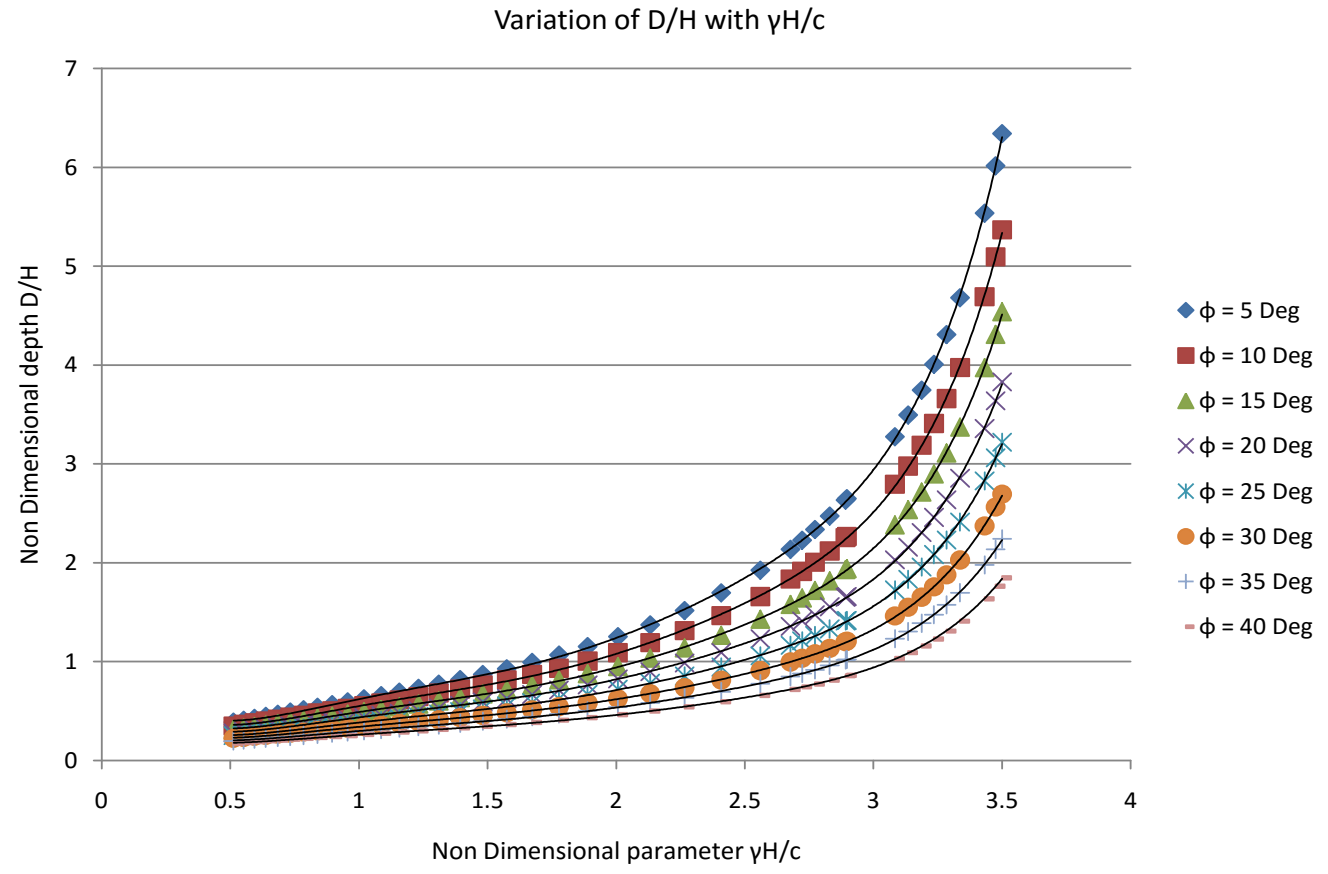

Fig. No. 13. Variation of D/H with $\gamma \mathrm{H} / \mathrm{c}$ for cantilever sheet pile wall 
The below given Fig. No. 14. shows the variation of $\%$ error or deviation of calculated values of $\mathrm{D}$ using the polynomials fitted for the data and the actual values calculated using equation (2). The deviations vary from $4.55 \%$ to $-4.02 \%$ which the author believes is well within the allowable range for sheet pile wall problem. Also one can notice that if this procedure of calculating $\mathrm{D}$, the embedment depth from the non dimensional parameter $\gamma \mathrm{H} / \mathrm{c}$, is limited over a range of $\gamma \mathrm{H} / \mathrm{c}$ between 0.6 to 3 , which is the normally recurring range of $\gamma \mathrm{H} / \mathrm{c}$ in sheet pile wall problems, then the values calculated are accurate to a margin of $1 \%$ to $-3 \%$.

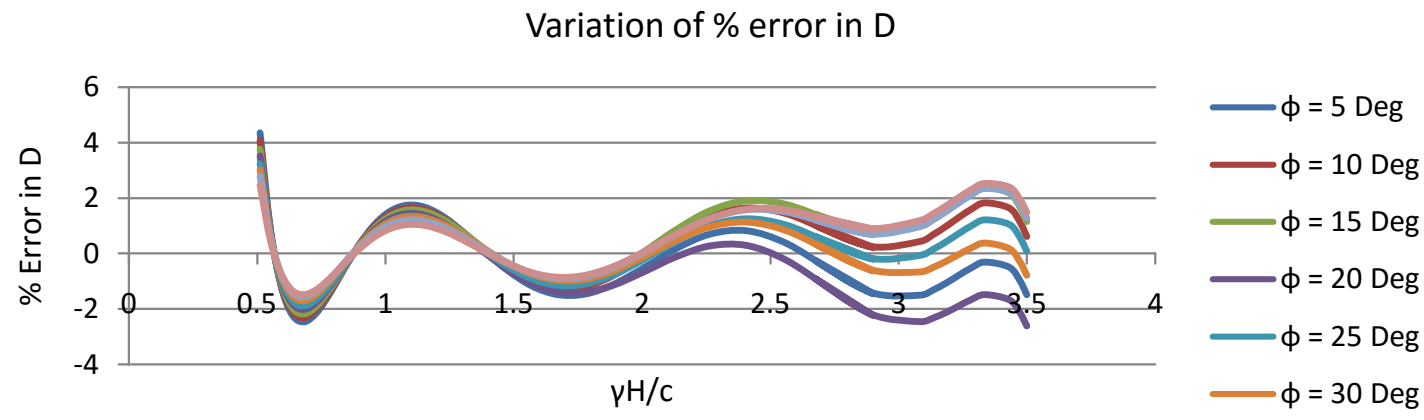

Fig. No. 14. Variation of $\%$ error with $\gamma \mathrm{H} / \mathrm{c}$

The above graph and equations for computation of embedment depth is for single layer of soil in the absence of water table with in it. However most practical sheet pile wall problems involve water table at some depth in the backfill and result in change of effective unit weight within the submerged depth. Then, in that situation the above solution cannot be used as it is developed for single soil layer for the entire depth of retainment.

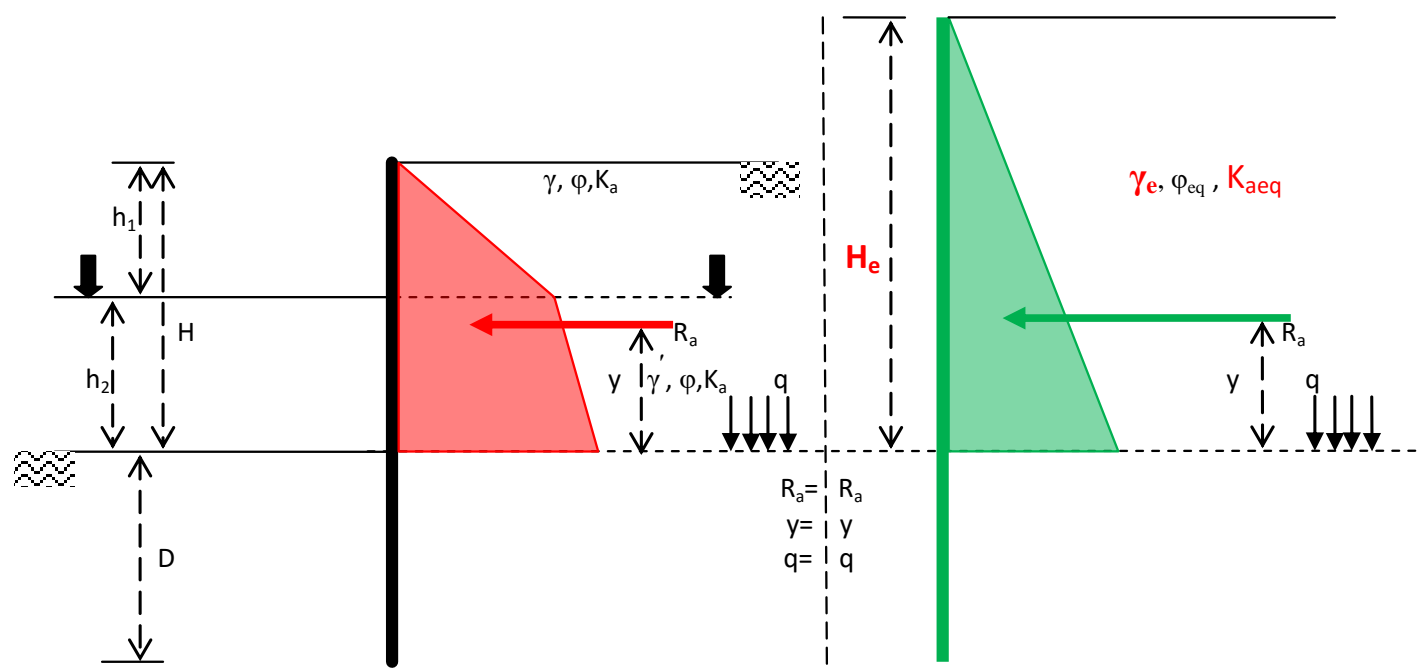

Fig. No. 15. Nomenclature associated with cantilever sheet pile wall

To overcome that difficulty the author suggests equating the given layer of soil having water table with in it to an equivalent single layer of soil, giving same total active earth pressure $\mathrm{R}_{\mathrm{a}}$ acting at the same height $\mathrm{y}$ from dredge line and causing same overburden pressure $\mathrm{q}$ upon the dredge line. In conjunction with the Fig. No. 15. the values of $\mathrm{H}_{e}, \gamma_{e}$ and $k_{a}$ eq can be shown to be calculated using the following equations for the equivalence condition.

$\mathrm{H}_{\mathrm{e}}=3 \mathrm{y}=3 \frac{\gamma h_{1}^{2} h_{2}+\frac{\gamma h_{1}^{3}}{3}+\gamma h_{1} h_{2}^{2}+\frac{\gamma h_{2}^{3}}{3}}{\gamma h_{1}^{2}+2 \gamma h_{1} h_{2}+\gamma^{\prime} h_{2}^{2}}$

$\gamma_{e}=\frac{\gamma h_{1}+\gamma^{\prime} h_{2}}{H_{e}}$

and

$$
k_{a e q}=\frac{k_{a}\left\{\gamma h_{1}^{2}+2 \gamma h_{1} h_{2}+\gamma^{\prime} h_{2}^{2}\right\}^{2}}{3\left\{\gamma h_{1}+\gamma^{\prime} h_{2}\right\}\left\{\gamma h_{1}^{2} h_{2}+\frac{\gamma h_{1}^{3}}{3}+\gamma h_{1} h_{2}^{2}+\frac{\gamma h_{2}^{3}}{3}\right\}}
$$

Now the soil layer above and below water table can be treated as single layer of soil of height $\mathrm{H}_{\mathrm{e}}$, unit weight $\gamma_{\mathrm{e}}$ and coefficient of active earth pressure $\mathrm{k}_{\text {aeq. }}$.

\section{ANCHORED SHEET PILE WALL}

Similarly efforts are made by the author to relate the embedment depth of anchored sheet pile wall with the non dimensional parameter $\gamma \mathrm{H} / \mathrm{c}$. In this case an additional parameter come into play viz., depth of anchor rod from the ground surface. Also attention is drawn to the fact that considered retained soil is sand and same for entire depth $\mathrm{H}$ of backfill and water table is absent within the affecting depth. 


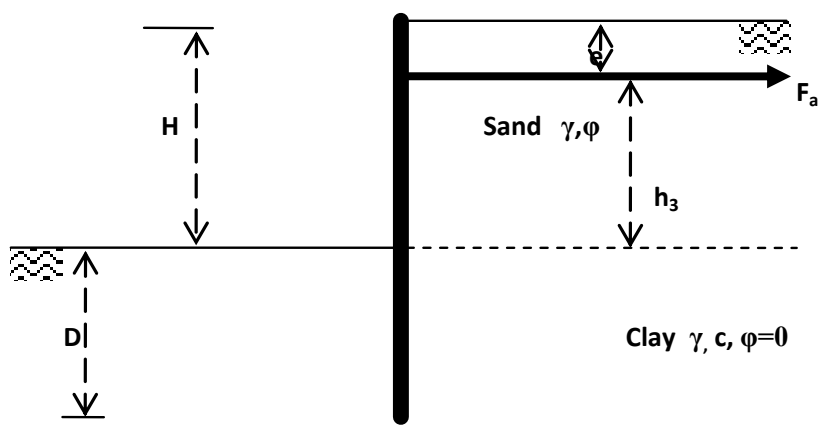

Fig. No. 16. shows an anchored sheet pile wall embedded in clay along with heights and relevant soil properties. The equation for embedment depth for equilibrium for an anchored sheet pile wall embedded in clay is

$$
D^{2}+D\left(2 h_{3}\right)-\left(2 R_{a} y\right) /(4 c-q)=0
$$

Fig. No. 16. Nomenclature associated with anchored sheet pile wall embedded in clay

Variation of $\mathrm{D} / \mathrm{H}$ with $\mathrm{\gamma H} / \mathrm{c}$

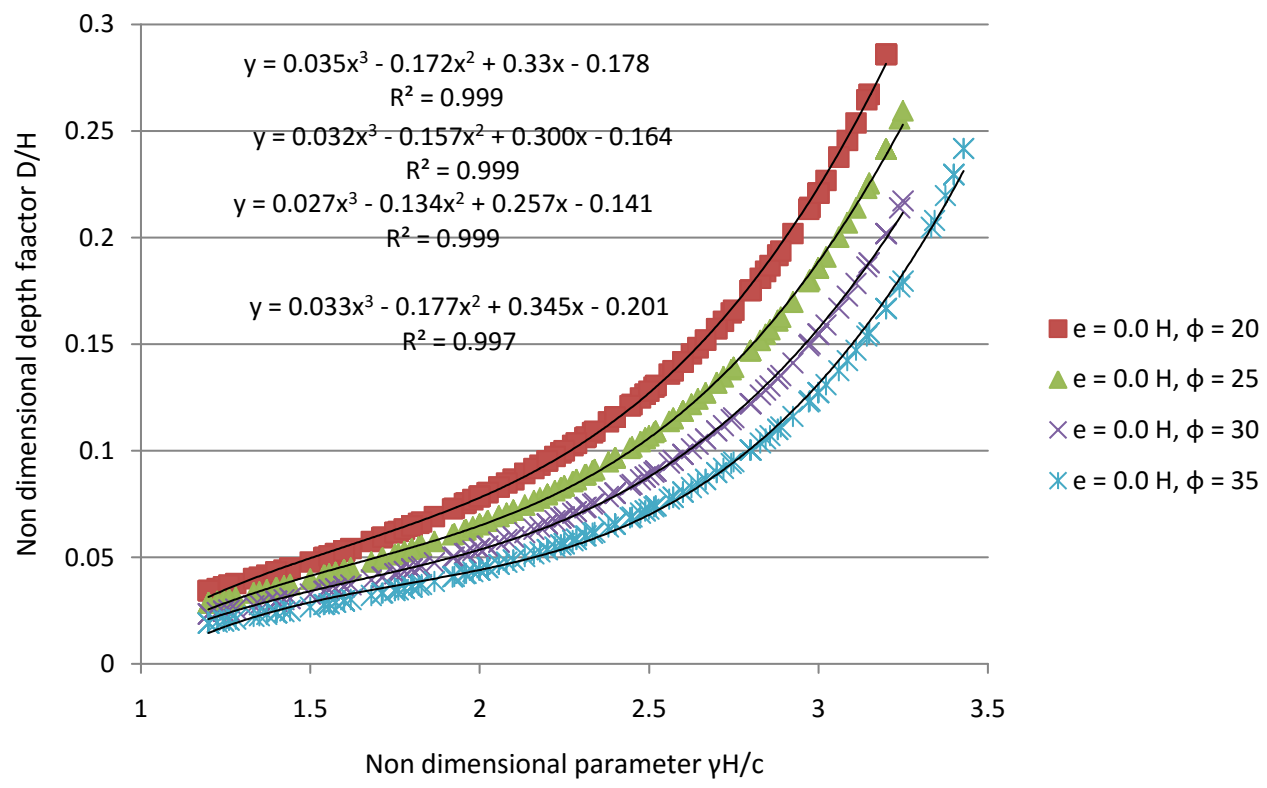

Fig. No. 17. Variation of D/H with $\gamma \mathrm{H} / \mathrm{c}$ for $\mathrm{e}=0.0 \mathrm{H}$

Fig. No. 17. depict the relationship between non dimensional parameters $\gamma \mathrm{H} / \mathrm{c}$ and $\mathrm{D} / \mathrm{H}$, where $\mathrm{D}$ is calculated using equation no (2), for an anchored sheet pile wall retaining sand and embedded in clay. The chart gives the relationship for anchor rod at the ground surface, i.e., e = $0.0 \mathrm{H}$.
Likewise Fig. Nos. 18, 19, 20, 21. gives the relationship between non dimensional parameters $\mathrm{D} / \mathrm{H}$ and $\gamma \mathrm{H} / \mathrm{c}$ for anchored sheet pile wall embedded in clay and for anchor rod depths equal to $0.1 \mathrm{H}, 0.2 \mathrm{H}, 0.3 \mathrm{H}$ and $0.4 \mathrm{H}$ respectively.

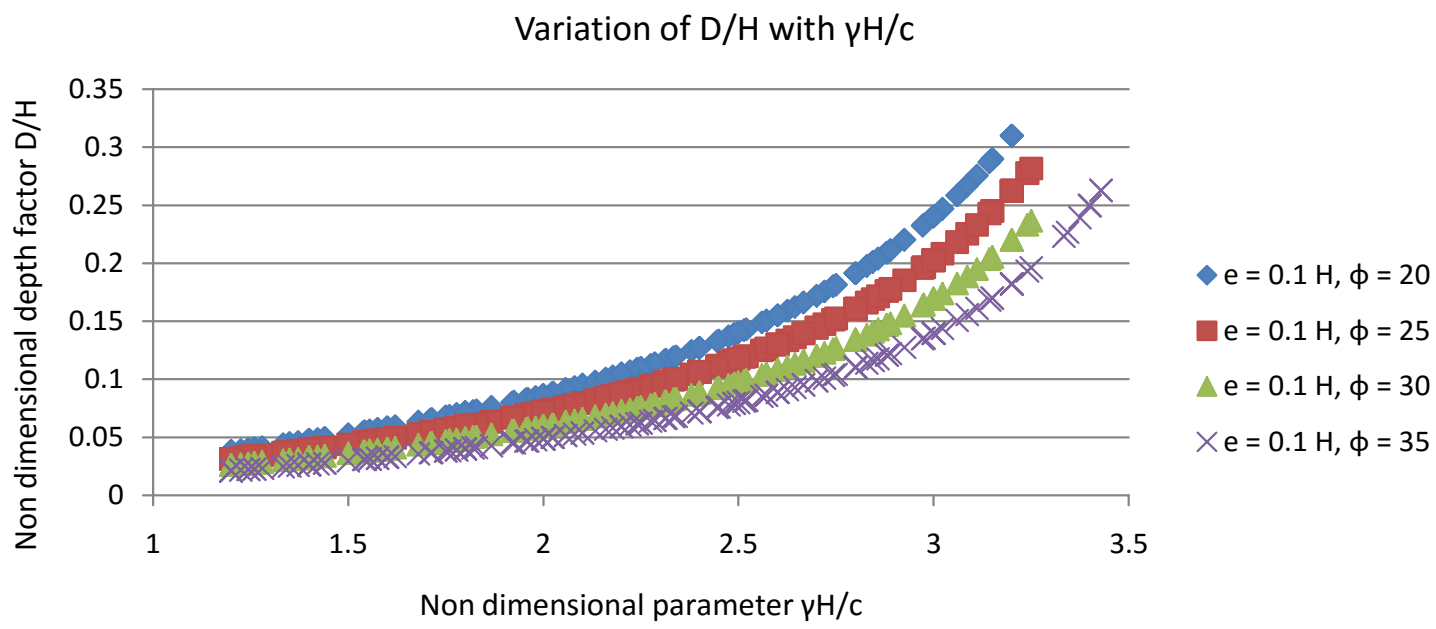

Fig. No. 18. Variation of $\mathrm{D} / \mathrm{H}$ with $\gamma \mathrm{H} / \mathrm{c}$ for $\mathrm{e}=0.1 \mathrm{H}$ 


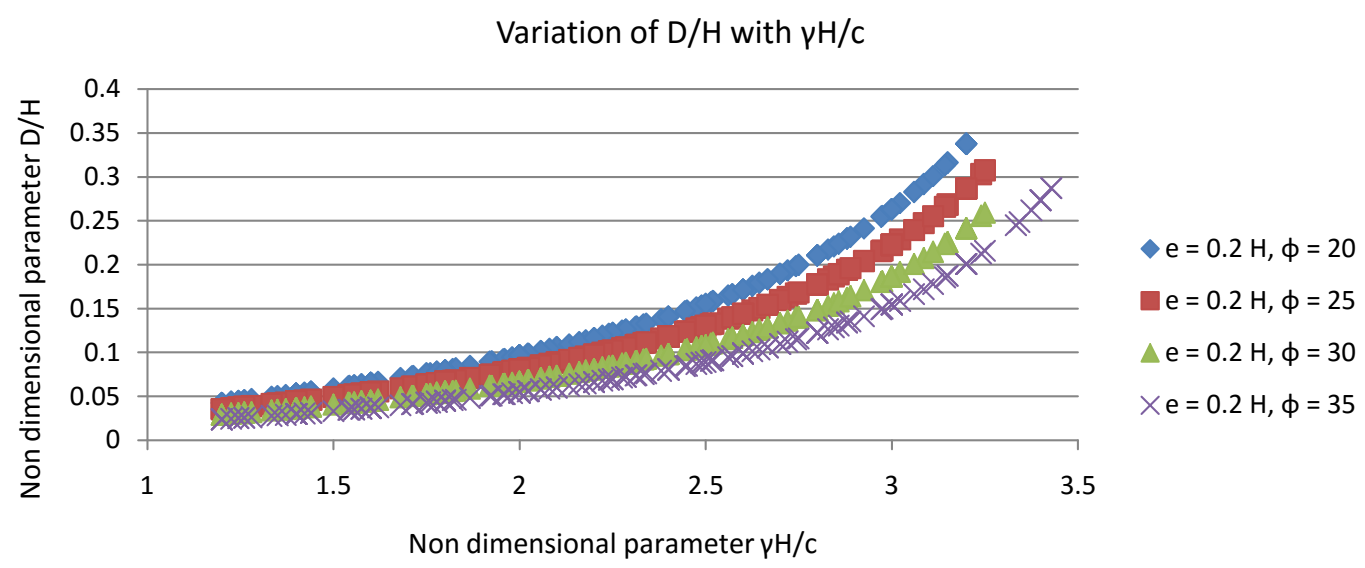

Fig. No. 19. Variation of $\mathrm{D} / \mathrm{H}$ with $\gamma \mathrm{H} / \mathrm{c}$ for $\mathrm{e}=0.2 \mathrm{H}$

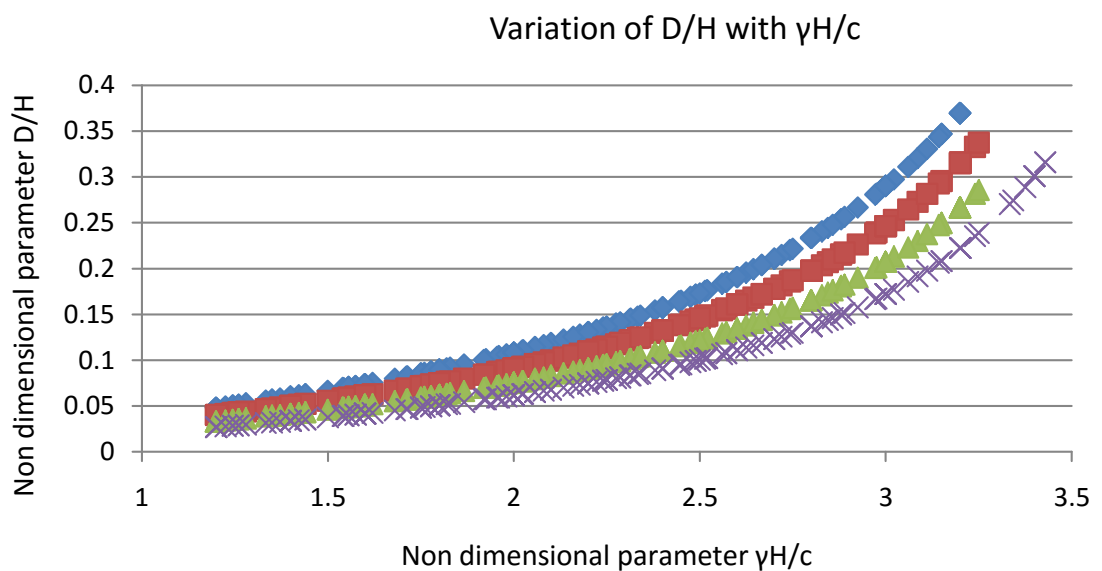

$\begin{aligned} & \Delta \mathrm{e}=0.3 \mathrm{H}, \phi=20 \\ & \mathrm{e}=0.3 \mathrm{H}, \phi=25 \\ & \Delta \mathrm{e}=0.3 \mathrm{H}, \phi=30 \\ & \times \mathrm{e}=0.3 \mathrm{H}, \phi=35\end{aligned}$

Fig. No. 20. Variation of $\mathrm{D} / \mathrm{H}$ with $\gamma \mathrm{H} / \mathrm{c}$ for $\mathrm{e}=0.3 \mathrm{H}$

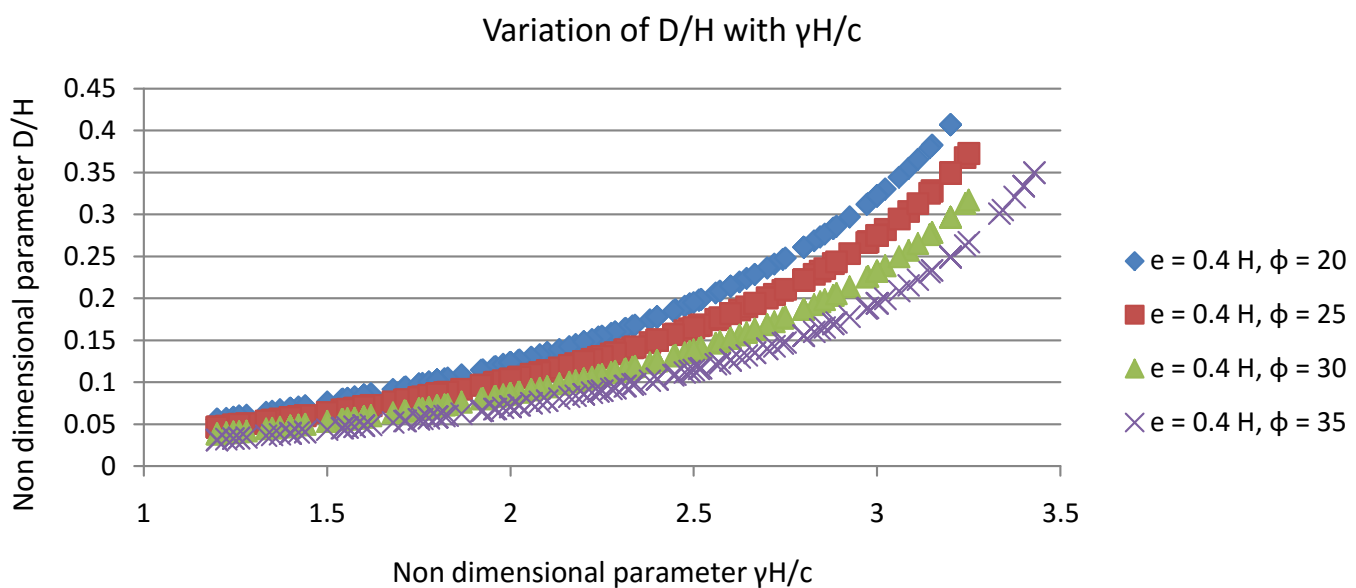

Fig. No. 21. Variation of $\mathrm{D} / \mathrm{H}$ with $\gamma \mathrm{H} / \mathrm{c}$ for $\mathrm{e}=0.4 \mathrm{H}$

As discussed in the case of cantilever sheet pile wall, most practical sheet pile wall problems involve water table at some depth in the backfill and result in change of effective unit weight within the submerged depth. Then, in that situation the above solution cannot be used as it is developed for single soil layer for the entire depth of retainment.

To overcome that difficulty the author suggests to equate the given layer of soil with an equivalent single layer of soil, giving same total active earth pressure $\mathrm{R}_{\mathrm{a}}$ acting at the same height $\mathrm{y}$ from dredge line and causing same overburden pressure $q$ upon the dredge line. The values of $H_{e}, \gamma_{e}$ and $k_{a e q}$ of the equivalent single layer of soil has to be calculated as discussed in the case of cantilever sheet pile wall and embedment depth for equivalent soil layer can be determined which will be same as the embedment depth for the given problem. 


\section{CONCLUSIONS}

There exists a correlation between non dimensional depth $\mathrm{D} / \mathrm{H}$ and a non dimensional parameter $\gamma \mathrm{H} / \mathrm{c}$ using which conveniently embedment depth can be calculated both for cantilever and anchored sheet pile walls embedded in clay soils and retaining single layer of sand without water table.

The same relationship can be employed to determine the embedment depth even when water table exists in the retained soil equating it to an equivalent single layer of soil.

The relationship developed is simple with realistic and rational soil properties and geometry of sheet pile wall.

Charts developed are simple, comprehensive and easy for use.

\section{REFERENCES}

[1] Bowles, E. Joseph., Foundation Analysis and Design., Fifth edition, The McGraw-Hill Companies, Inc.,1997.

[2] Das, M Braja., Principles of Foundation Engineering., Sixth edition, Thomson, 2007.

[3] Hagerty,D.J., and Nofal,M. M. (1992). "Design Aids: Anchored Bulkheads in Sand," Canadian Geotechnical Journal, Vol. 29, No.5, pp. 789-795.

[4] Nataraj, M. S., and Hoadley, P. G. (1984). "Design of Anchored Bulkheads in Sand," Journal of Geotechnical Engineering, ASCE, Vol. 110, No. GT4, pp. 505-515. 